Article

\title{
The Importance of Indigenous Cartography and Toponymy to Historical Land Tenure and Contributions to Euro/American/Canadian Cartography
}

\author{
Daniel G. Cole ${ }^{1, *}$ and E. Richard Hart ${ }^{2}$ \\ 1 Smithsonian Institution, National Museum of Natural History, IT Office, MRC 136, \\ Washington, DC 20013-7012, USA \\ 2 Hart West and Associates, Winthrop, WA 98862, USA; erhart@methownet.com \\ * Correspondence: coled@si.edu
}

Citation: Cole, D.G.; Hart, E.R. The Importance of Indigenous Cartography and Toponymy to Historical Land Tenure and Contributions to

Euro/American/Canadian Cartography. ISPRS Int. J. Geo-Inf. 2021, 10, 397. https://doi.org/ 10.3390/ijgi10060397

Academic Editors: Fraser Taylor, Romola V. Thumbadoo and Wolfgang Kainz

Received: 13 April 2021

Accepted: 31 May 2021

Published: 8 June 2021

Publisher's Note: MDPI stays neutral with regard to jurisdictional claims in published maps and institutional affiliations.

Copyright: (c) 2021 by the authors. Licensee MDPI, Basel, Switzerland. This article is an open access article distributed under the terms and conditions of the Creative Commons Attribution (CC BY) license (https:/ / creativecommons.org/licenses/by/ $4.0 /)$.

\begin{abstract}
Indigenous maps are critical in understanding the historic and current land tenure of Indigenous groups. Furthermore, Indigenous claims to land can be seen in their connections via toponymy. European concepts of territory and political boundaries did not coincide with First Nation/American Indian views, resulting in the mistaken view that Natives did not have formal concepts of their territories. And Tribes/First Nations with cross-border territory have special jurisdictional problems. This paper illustrates how many Native residents were very spatially aware of their own lands, as well as neighboring nations' lands, overlaps between groups, hunting territories, populations, and trade networks. Finally, the Sinixt First Nation serve as a perfect example of a case study on how an Aboriginal people are currently inputting and using a GIS representation of their territory with proper toponymy and use areas.
\end{abstract}

Keywords: Native Americans; first nations; historic cartography; toponymy

\section{Introduction}

Although Native Americans/American Indians/First Nations did not originally have access to paper for their map creation, many of them nonetheless had excellent cognitive cartography concerning their environment, settlements, populations, territories, trails and trade routes. They were often able to communicate this spatial knowledge to EuroAmericans who were mapping said lands by drafting maps (on paper, deerskin, or on the ground in dirt and snow) and providing place-names. These maps and toponymy essentially describe how well Indigenous peoples understood the geography of their lands. In recent years, many libraries and archives have started digitizing their collections, thus making maps by Indigenous peoples more easily available for scholars to study. Although a number of these maps were discussed by G. Malcolm Lewis in the History of Cartography series (volume 2, book 3, Chapter 4: 1984), more have since been found and disseminated. Before continuing, it must be noted that in historical cartography, G. Malcolm Lewis is the standard-bearer for scholarship in this arena [1-4].

Additionally, many Euro-American explorers would get lost without Indigenous help while traversing the North American landscape. Alternatively, sometimes Native guides intentionally led Europeans astray. This paper will illustrate the fact many Native residents were very spatially cognizant of their own lands, as well as neighboring nations' lands, overlaps between groups, hunting territories, populations, and trade networks.

\section{Materials and Methods}

Throughout the course of this research, we have gathered numerous historic and contemporary maps and map-related materials from various archives, libraries and other holdings. From these compiled maps and archival files, as shown below, we have built 
extensive evidence of Indigenous cognitive cartographic knowledge and physical cartographic abilities. For sources, we made use of digitized maps and explorers' logs that were downloaded from numerous First Nation, tribal, state, provincial, national, university and museum archives and libraries. Derived from these digital records, we have collected mapped examples of Native toponymy and territories as well. Regarding the example of the Sinixt for the current state of Indigenous knowledge, we relied on their traditional ecological knowledge of the surrounding rivers, lakes, mountains, and hunting and fishing locations.

In order to create their place-names map, the Sinixt identified historic sources that documented Sinixt toponymy. Latitude and longitude coordinates for the locations were carefully recorded, and were sometimes more general than specific, depending on the cultural importance of the location (burials were not included). Orthography of the place names was standardized and information about each place was discussed to determine what information could be made public.

\section{Colonial Period}

From the start, European mapmakers relied on Native informants, as can be seen in Samuel de Champlain's map of New France (1612) [5] and John Smith's map (1624) [6] of the Virginia and Chesapeake region, which contain spatial data beyond their explorations. Hermann and Pearce (2008) mapped out Champlain's travels from the Gulf of St Lawrence to Georgian Bay with notes from Champlain, imagined notes from Native voices, and the cartographers' notes. The title, They Would Not Take Me There, is indicative of Champlain's desire to find a route to James Bay [7]. On Smith's map, crosses are placed to indicate the limits of his travels, and beyond those crosses were named Indian territories and towns provided by his Native informants.

One of the earliest surviving Native maps in North America was in the Southeast-the Catawba Deerskin Map (ca. 1720), which abstractly encompassed the social and trade network of the Catawba, along with those of their Native and English neighbors [8]. In the Plains, as noted by Cole (2021), "in 1752, Philippe Buache compiled two maps on one sheet including a possible water route from the Lake Superior to the Pacific from Ochagach (Cree) (Figure 1) and a second map of the northern Plains from two unpublished maps by French fur traders. These two maps illustrated territories of the Assiniboils (Assiniboine), Cristinaux or Cristinots (Cree), the Monsoni (Ojibwe) and the Sioux. This map is the first printed record from the Plains of an Indigenous map" [9-11].

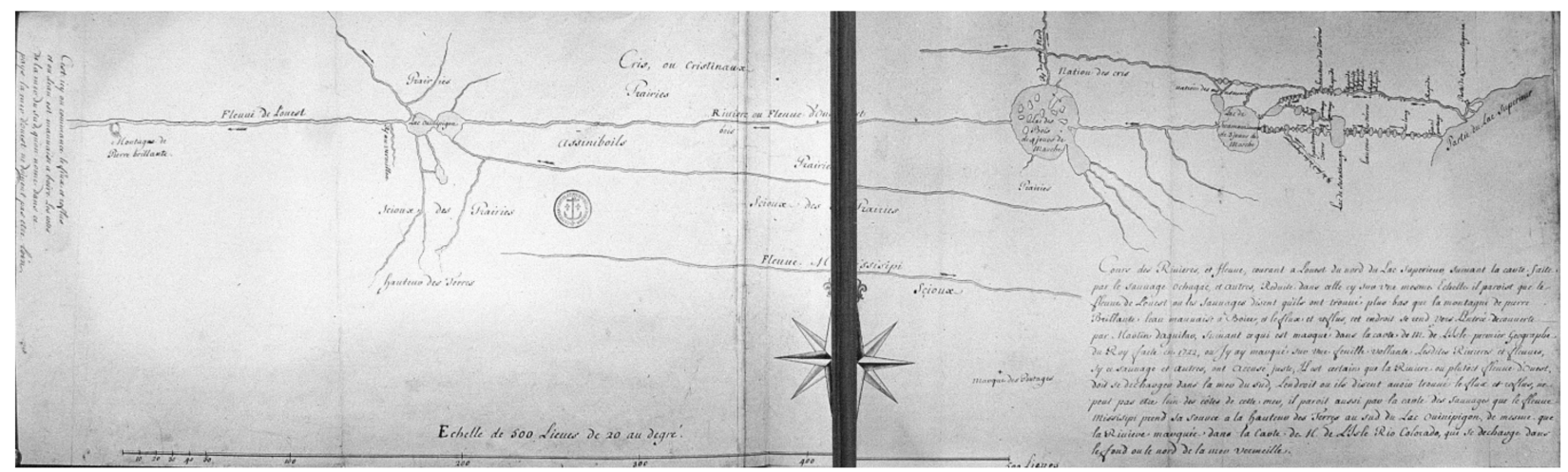

Figure 1. Map by Ochagach (Cree), traced by Philipp Bauche, of a water-bound route between Lake Superior and the unknown distant west. Downloaded and cropped from the Research Laboratories of Archaeology at the University of North Carolina.

Chegeree (unknown tribe) drafted a map of the Ohio River valley from his travels from Lake Erie to the Mississippi River (ca. 1755), which was created for the British as intelligence information at the start of the French and Indian War with locations of a French fort (Fort Duquesne), Indian settlements and distances [12]. During the same war, 
an unidentified Indian scout provided help to John Montrésor, creating a sketch map of the battlefield at the Monongahela [13]. Red Head (Onondaga) created a sketch map in 1759 of the area from Lake Ontario to Montreal [14]. As Lewis (2004: 15) notes, the map provided "valuable intelligence not the least for its relatively detailed representation of Chaumont and Black River Bays at the eastern extremity of Lake Ontario and possible routes from there to La Galette (Oswegatchie on the "draft") that avoided the treacherous Thousands Islands reach of the main river." The strategic intelligence on the map included the locations of Indian settlements, French forts, carrying places (portages) around rapids and Indian footpaths.

Most Euro-American maps seem to either ignore the presence of Indigenous peoples or treated them as an addendum. One particular exception was created by John Gerar William De Brahm, who mapped the Indian Nations of the Southern Department in 1766. Although the underlying base map is more of a sketch than many of its contemporaries, this map contains a wealth of information on the Native toponymy of Indian towns and territories, although the latter has the anglicized versions of the tribal names [15].

In 1767, two Native cartographers, Matonabbee and Idotlyazee (Chipewyan or Denesuline) mapped a very large area in Canada for the Hudson's Bay Company (HBC) from the Churchill River north to Coronation Gulf, and from Hudson Bay to the Great Slave Lake. June Helm spatially analyzed this map, taking note of the extensive distortion (east-west distances are greatly shortened) on the map. Nonetheless, she marveled at how knowledgeable the two men were of their extensive travels across the landscape, encompassing hydrology and other physical markers [16].

An unknown Comanche drafted a large-scale map, illustrating "an engagement in the Spanish frontier province of New Mexico between the Comanche and their traditional enemy, the Mescalero Apache. According to an accompanying document signed by then Governor Juan Bautista de Anza, the pictographic map documents illustrate the Battle of Sierra Blanca, 30 July 1787" [17,18]. This map exemplifies a depiction of a battle, which commemorates a special event that the victors wanted to remember, including deaths and injuries of people and horses, along with the number of prisoners taken.

\section{19th Century-Early 20th Century}

In 1801 and 1802, Ac Ko Mok Ki (a Blackfoot chief) drew two maps (at least one of which was told orally and drawn in the snow) for the HBC staff that were redrawn and annotated by Peter Fidler (Figure 2). Although the HBC was concerned with tribal territories and hunting areas for purposes of trade/profit, Fidler was nonetheless very impressed by the geographic knowledge of Ac Ko Mok Ki concerning the drainage network of rivers connecting the Rocky Mountains to the Missouri River. The rivers and 11 mountain peaks were all assigned names by Ac ko mok ki using traditional knowledge, and included descriptions of the adjacent plains, covering a distance of over 500 miles [19,20]. 


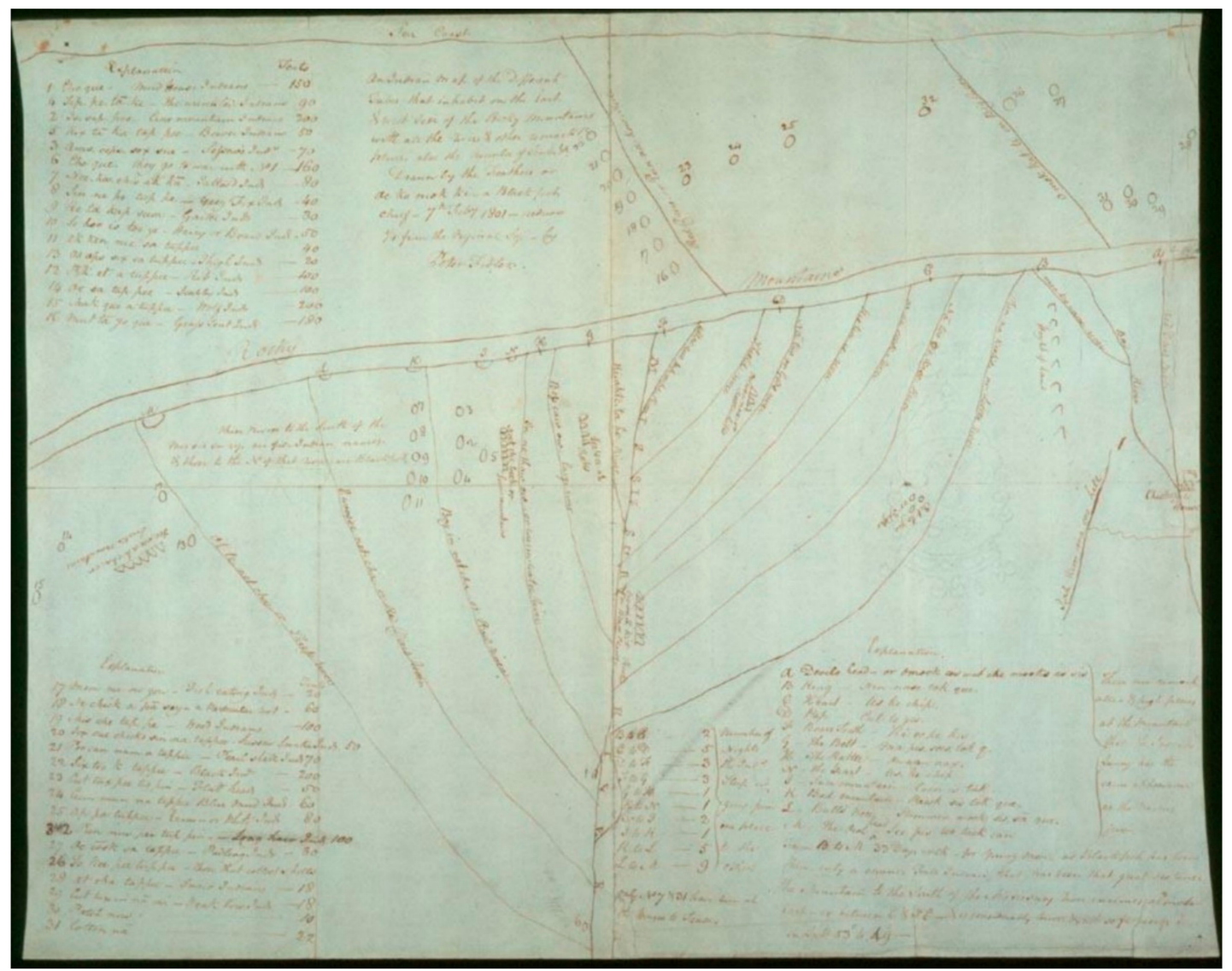

Figure 2. Map by Ac ko mok ki of the drainage network from the Missouri River to the Rocky Mountains, with annotations by Peter Fidler. Downloaded from the Hudson's Bay Company Archives.

Christopher Steinke found a map made by Too-Né, an Arikara chief, while pursuing his doctoral research in the French National Library. Steinke notes that it "captures some of the Arikara history that William Clark left unrecorded. Drawn sometime in 1805 or early 1806, it shows the course of the Missouri River, Lewis and Clark in council at the Arikara and Mandan villages, the locations of more than thirty different Indian groups, and significant places in the history of the Arikara people" [21].

The Lewis and Clark expedition produced two notable maps in 1805 and 1814 from their exploration. Both maps had extensive demographic data related to Native settlements, a large portion of which was far from the expedition's outbound and return routes. The earlier map merely identified the numbers of warriors or men, but on the latter map, the numbers of souls were noted, which probably included women and children. Neither the locations of the settlements nor the numbers of inhabitants could have been shown without the input of Indigenous informants [22,23]. Gribb and Cole (2014) spatially analyzed these data sets and found that:

"The positional accuracy of the Lewis and Clark maps was measured using the RMSE method and providing a standard for the maps of $276.3 \mathrm{~km}$. The error increases as the tribal groups have less contact with Lewis and Clark along their route, thus the speculative nature of their placement identifies the problems they encountered by using secondary source information ... The population counts listed for the different tribal groups, either on the maps or in the table, have some of the same shortcomings, however, with this attribute were two sources upon which to compare and analyze the population values - the Mooney values of 1928 and the Handbook values from a number of historical demographers/ethnographers. In the four comparisons, between the Lewis and Clark statistics for the Great Plains and the Pacific Northwest to Mooney and the Handbooks, we 
found that statistically there is no difference. Overall, the Lewis and Clark population values are a reliable source of population statistics for 1804-1806" [24-26].

In 1822, William Edward Parry, together with two Inuit, Iligliuk and Ewerat, mapped Inuit place names around Melville Peninsula in the Canadian Arctic. On one map, settlements included notations on Ookotook's Country, an 'Inhabited' area and Eskimaux (Inuit) Huts with notes from Iligliuk, e.g., "The Ships seen from here by Ookotook". The other map had Indigenous place names acknowledging Ewerat, including a note about the limits of Ewerat's geographic knowledge. Additionally, Lewis noted that "Parry was explicit in his opinion that better-quality maps could be obtained from the Inuit by providing a chart of land already known and asking for it to be extended," and presented a map drawn by Illigliak (an Inuit woman) and Parry of the northern Melville Peninsula and nearby portions of Baffin Island [27,28].

Two significant Indigenous maps were discussed by Lewis (1984): in 1825, GeroSchunu-Wy-Ha (Oto) drafted a map that "traces the route of an Oto war party that attacked the Arapahos in the area between the upper Arkansas and upper Cimarron rivers. The events are depicted in typical Indian pictographic style against a network of rivers. The gross distortion of the network reflects the constraints imposed on the Indian by the rectangular sheet of paper. Even so, it is a remarkable map, covering about a third of a million square miles of the northern and Central American plains." (pp. 98-100). In addition, Non-Chi-Ning-Ga (Iowa) created a map in 1837 of tribal migrations in the Upper Mississippi and Missouri river basins. For both maps, Lewis redrew the maps and manually geo-referenced them against modern maps of the same areas, showing how well the two Native cartographers fared in their depiction of rather large drainage networks [29].

Joseph Nicollet published a hydrological map in 1843 of the Upper Mississippi drainage basin as part of the Fremont expedition of the War Department in the 1830s. What is important with this map is that, in addition to identifying more than a dozen Indian nations occupying the landscape, plus notations on their hunting and fishing grounds, he included both Indigenous and English names for many of the rivers, lakes, and buttes. Although these Indigenous names did not appear out of Nicollet's imagination, the source(s) of the place names is not given [30-32].

From the 1830s to the 1850s, Father Pierre-Jean De Smet drafted numerous maps dealing with the Native peoples of Canada and the U.S. from the Great Plains and Rocky Mountains west to the coasts of Oregon and British Columbia. A number of these maps incorporated help from Indigenous informants and cartographers. His most well-known map illustrates Native territories across the Plains to the Columbian Plateau and was drafted for the U.S. government in 1851. Other maps of his include numerous watersheds extending east and west of the Rockies, Native villages, and mission activities. On two of his maps, Station (sub-mission) St Pierre des Lacs along the upper Columbia River and Ft. Colville are cited, which both served the Sinixt. In addition, two Indigenous-made maps in the Pierre-Jean De Smet Map Collection at the Jesuit Archives and Research Center include one titled, Indian Map of the Two Coeur d'Alene Upper Forks by an unknown person, and another by Victor, chief of the Salish Indians, both of which were likely used by De Smet when he compiled the spatial data for his maps [33,34].

Another example of the good spatial cognition held by Native Americans is on a map drawn by an anonymous Assiniboine warrior in 1853 of the northern Missouri River from North Dakota to north central Montana. On the map are notations by Edwin Denig that read, "Map of the north side of the Missouri river from Fort Union, mouth of the Yellow Stone, to Fort Benton, mouth of the Maria, drawn by an Assiniboine warrior at Fort Union 27 December 1853. The artist was not acquainted with the country on the south side of the Mo. The dotted line is their usual war path to the Blackfeet. Names of rivers \& c. written under his direction and explanation." Warhus (1997) added "that the Assiniboine's map was not made to give a western oriented picture of the landscape; like much of the Plains picture writing it was made to record the warpath of the anonymous brave making a raid on the Blackfeet in Montana" [35,36]. 
The Smithsonian's National Anthropological Archives has a collection of maps by Inuit cartographers with annotations by Franz Boas of the Baffin Island area, created in 1883 (Figure 3). As noted by the Archives, "Most of the maps are not identified as to the precise area they represent except by Eskimo [Inuit] place names. Other notes on the maps include a short text in Eskimo and some notes in German and English; most of these notes are illegible, because Boas used a shorthand system of his own in writing many of them, and his handwriting is very difficult to read even when not abbreviated" [37]. Nonetheless, given time, a cartographic researcher could probably match up a number of these maps by researching the Boas journal and by overlaying the maps on current high-resolution imagery or maps of Baffin Island.

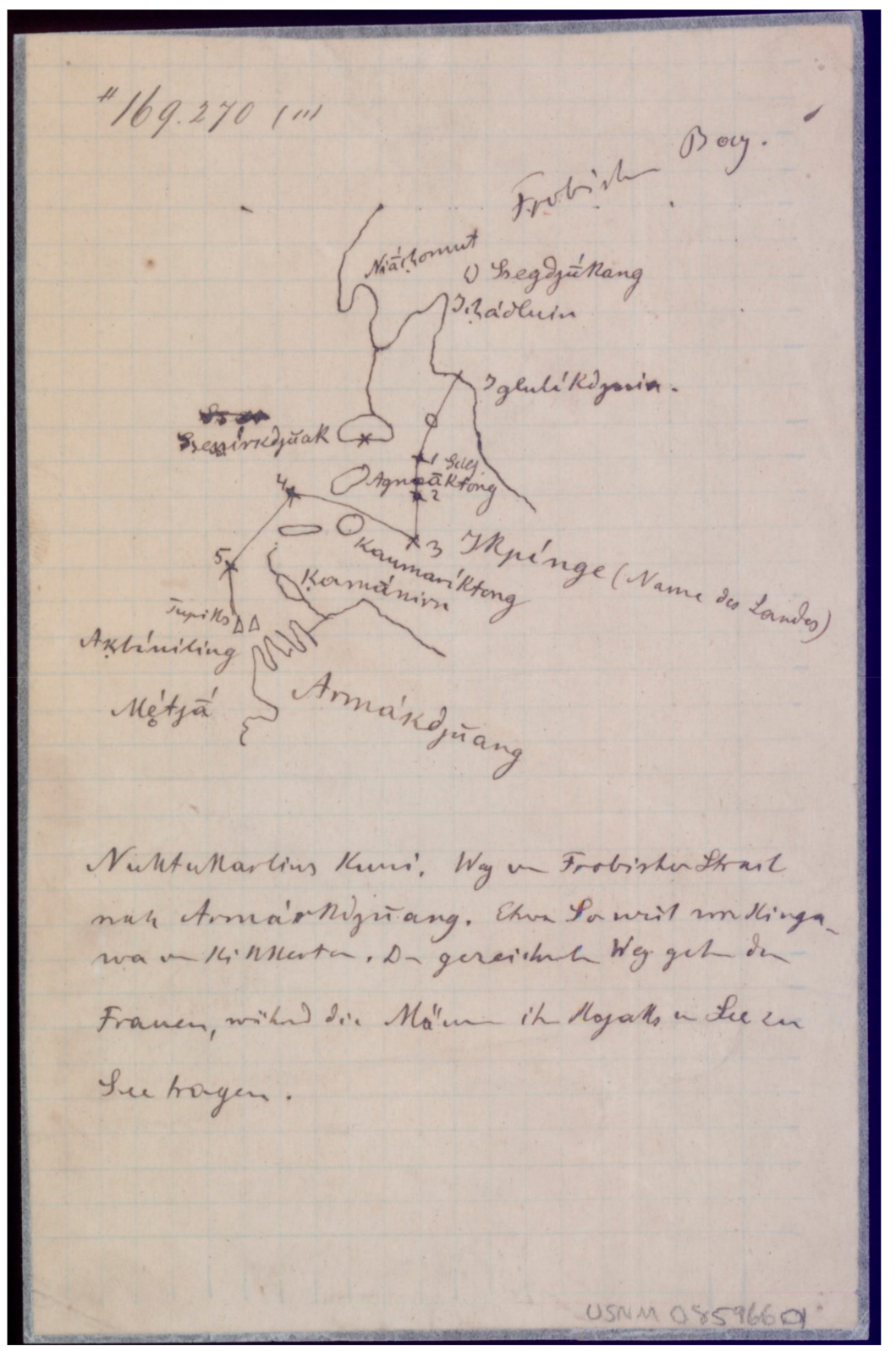

Figure 3. Map by anonymous Inuit and annotations by Franz Boas. Downloaded from the National Anthropological Archives of NMNH.

At the end of the 19th century and the beginning of the 20th century, three Indigenous cartographers, Crazy Mule (Cheyenne), Black Goose (Kiowa) and Amos Black Heart Bull (Oglala Lakota) drafted pictographic maps of events between their peoples, the U.S. government and other tribes [38-40]. These maps did not deal with toponymy, per se; 
rather, they used name-glyphs to identify Indian and White settlements, military forts, battles, rivers, mountains, and other physical features; and they portrayed multiple events occurring within individual spatial frames.

An unsuccessful proposition to create the State of Sequoyah was mapped by D.W. Bolich (Muskogee) in 1905. His cartographic effort was part of an attempt by the Five Civilized Tribes (Choctaw, Chickasaw, Muscogee, Cherokee and Seminole) to prevent being admitted to the United States as a part of a joint state made of both the Indian and Oklahoma Territories. Had it been successful, the name Sequoyah as chosen was in homage to the compiler of the Cherokee syllabary [41].

Lewis (1984: 118) points out that during 1914, Ishi, who was said by Kroeber to be the last of the Yahis, "was a member of an expedition to his people's former territory between Mill Creek and Deer Creek. The expedition "led by Ishi ... covered a large part of Yahi ancestral territory, mapped it in detail, with village sites, trails, hidden brush shelters, and the smoke-lined caves ... exactly located and named. On the maps were more than two hundred native place names" (Theodora Kroeber, Ishi in Two Worlds: A Biography of the Last Wild Indian in North America, University of California Press: Berkeley, CA, USA, 1961, pp. 215-216). The precise nature of Ishi's mapping input is unknown. The field maps have apparently not survived. Either they or a smaller map by Ishi seem to have been the basis for the map shown here. From A. L. Kroeber, Handbook of the Indians of California, Bureau of American Ethnology Bulletin 78, United States Government Printing Office: Washington, DC, USA: 1925, p. 344.

\section{Late 20th Century-Early 21st Century}

In recent decades, many Native American tribes and nations have taken up the use of Geographic Information Systems (GIS) and mapping tools to re-establish their connections to traditional lands and waters. Esri has published four editions of the Tribal GIS book with a number of 1-2 page case studies on indigenous spatial activities. The Bureau of Indian Affairs, Branch of Geospatial Support provides GIS software and training to Native nations and tribes, with additional help provided by TribalGIS.com [42-47]. As a result, many Tribes/First Nations today have their own GIS offices, employing tribal members trained in GIS.

An interactive map by Village Earth made allotments openly accessible to Pine Ridge Reservation residents. According to the Village Earth website, the Pine Ridge Land Information System "makes it possible for members of the Oglala Sioux tribe to: Search for individually allotted and Tribal owned trust lands using the Tract ID; View, print and share a web link for the boundaries of specific land tracts" [48,49].

For Canada, an interactive Story Map (The Naonaiyaotit Traditional Knowledge Project Atlas) was cooperatively created by the Kitikmeot Inuit Association, Dalhousie University, Dominion Diamond Mines and Esri Canada. This website has maps of First Nation territories; Indigenous place names; heritage; travel routes and gathering places; water quality; and numerous mammal, bird and fish ranges and migration areas in the Nunavut and Northwest Territories of Canada [50]. An interactive bilingual (Inuit and English) map by Indigenous and Northern Affairs Canada delineates the four Inuit regions (Inuvialuit, Nunavut, Nunavik and Nunatsiavut) with all of the First Nation settlements in those regions, but nothing more. Hopefully, the website will contain more spatial information in the future [51]. The Gwich'in Place Names and Story Atlas allows users to interactively select towns, trails, mountains and rivers, with pop-up text discussing the stories related to each feature [52]. In addition, the Firelight Group has done some very good work with helping Indigenous communities map out the locations they and their families rely on for hunting, trapping, fishing and other important activities using traditional knowledge and use (TUS) studies, as well as Indigenous planning and ecology studies [53,54].

A poster map titled Coming Home: Indigenous Place Names of Canada by Margaret Wickens Pearce (2017) depicts place-names from First Nations, Métis and Inuit communities. 
Indigenous toponymy, whether in Canada or in the United States, has always been part of the cognitive cartography of Native peoples. As Pearce notes on the website, "The map does not depict all of the Indigenous place names of Canada, nor are all Indigenous Nations and communities represented. Beyond the map's names are thousands upon thousands more, an ever growing and expanding atlas of intimate, geographical knowledge and experience" [55].

\section{The Sinixt}

The Sinixt people speak an Interior Salish language and have occupied their aboriginal homeland for centuries, along the Columbia River, from Kettle Falls in the United States to above Revelstoke in British Columbia. Like many Columbia Plateau peoples, they lost a great portion of their population in the late 18th century to smallpox and other European diseases. At the time of contact with Europeans, they had central political organization and had defended their territory against interlopers. They welcomed trade with fur companies, were regarded as great hunters and adopted the use of trade items, including guns, metal pots and pans and canvas.

The Sinixt people today are struggling with Native toponymy issues related to the Canadian government's declaration in 1956 that they were extinct. The problems of the Sinixt are compounded by the fact that their traditional aboriginal territory includes land in both Canada and the United States. In the United States, the Indian Claims Commission legally defined the Aboriginal territory of tribes, relying largely on the testimony of nonIndian anthropologists and other witnesses. In Canada, different definitions and legal rulings mean that there are special problems for Aboriginal peoples who have traditional lands on both sides of the international boundary.

One of these issues has been the development of hydroelectric power in the traditional homelands of indigenous people, including the Sinixt. In 1956, the British Columbia Natural Resources Conference published an atlas titled the British Columbia Atlas of Resources [56]. The British Columbia Natural Resources Conference reported that "after ten years examination and evaluation of British Columbia's natural resources...," and with the work of more than one hundred professionals, including top people in the government and industry [57], they were able to publish over forty maps covering geographical characteristics of the province and resource use in the province (contemporary and future). One of those maps showed the location of both developed and potential hydro-power, including at least eight developed sites and a number of additional sites that were not yet developed just north of the international boundary [58]. The narrative in the accompanying textual volume pointed out that British Columbia was at the time "almost wholly dependent on hydro-power" and that in the next twenty years the full potential of the Fraser and the Columbia Rivers would be necessary to meet the demands for expected power use in the province [59]. As the Canadian and British Columbian governments worked to develop hydroelectric facilities, they did not negotiate with the Sinixt or sign a treaty with them. In fact, in 1956, the Canadian government declared the Sinixt extinct.

For over a century, it had been well-known that the portion of the Columbia River which crossed the international boundary was territory of the Native people known as the Sinixt (Lakes or Arrow Lakes) Tribe. Indeed, the same 1956 British Columbia atlas included a map that showed Sinixt territory (Figure 4). 


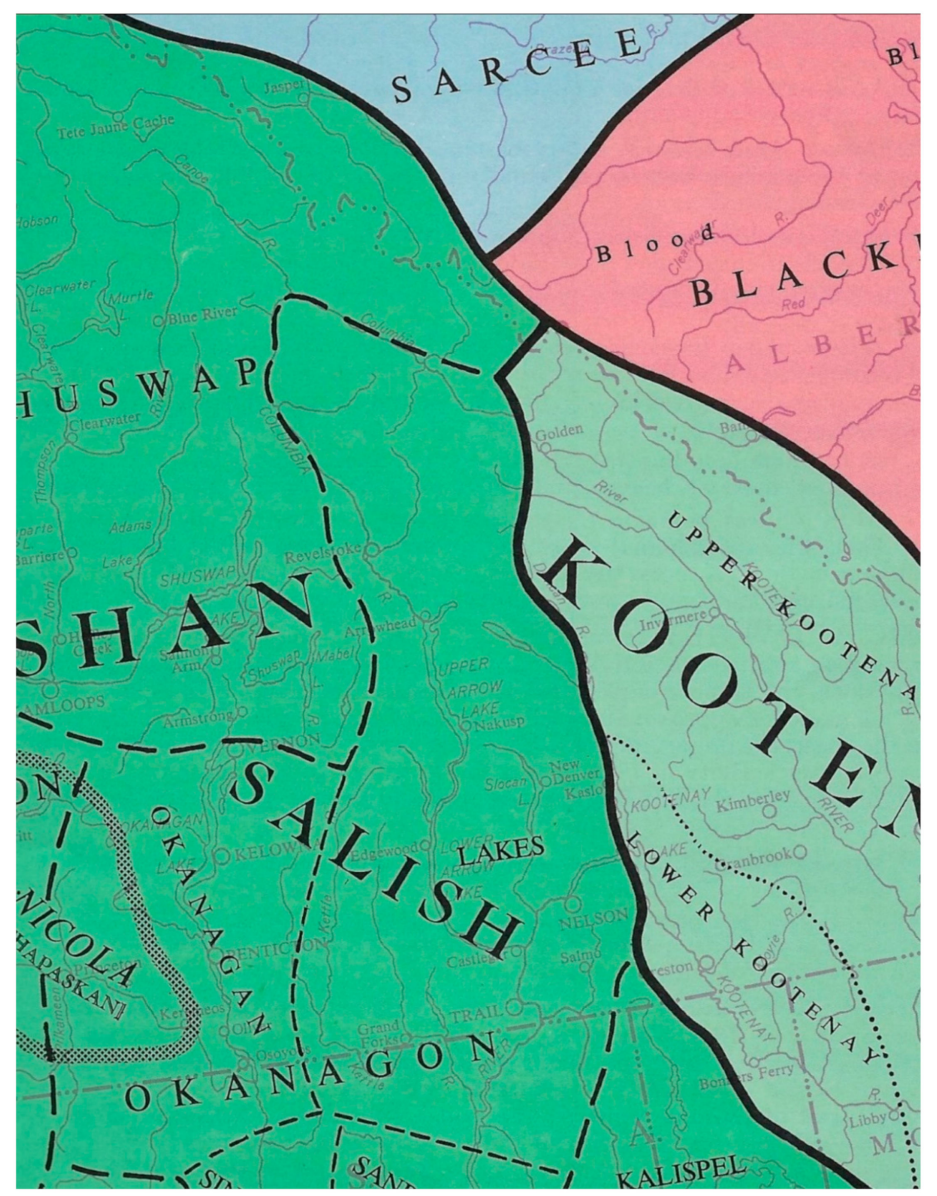

Figure 4. Sinixt (Lakes) as shown in Map 12 on pages 25-26 of the 1956 atlas created by the British Columbia Natural Resources Conference. The caption notes that the territory of the Lakes (Sinixt) is mapped as it existed in 1850.

It thus may be surprising that the federal Canadian government declared the Sinixt extinct during the same year, 1956 [60]. Late in the 19th century, Canada restricted Sinixt hunting. Between that time and 1956, the Sinixt were forced to relocate four different times, each time losing potential access to traditional lands and subsistence practices. Although it was profoundly hurtful to these people when Canada restricted their rights to hunt, declaring them extinct was not just insulting, but left a permanent scar on the communal psyche of the people. Since that time, many thousands of living Sinixt people have felt the effects of this action, and over a period of many decades, members of the Sinixt community have sought to have an audience in Canadian courts to demonstrate that they are not extinct and still have rights to their aboriginal homeland in today's British Columbia.

In 2010, Sinixt tribal member Richard Lee Desautel was cited for killing an elk in British Columbia without proper documentation. Desautel's defense was that he was hunting in his people's age-old aboriginal territory, and that as such, he was entitled to hunt there. The trial was finally held in 2016, and in 2017 the judge who presided over that trial issued a decision, ruling not only that the Sinixt were not extinct, but that Mr. Desautel did indeed have a right to hunt within his people's aboriginal territory [61]. Since 2017, two Canadian appellate courts have confirmed the lower court's decision and the ruling went before the Canadian Supreme Court. On 23 April 2021, the Supreme Court of Canada ruled that the Sinixt were not extinct and have constitutionally protected rights in their Aboriginal territory in British Columbia.

Under Canadian law, the determination of territorial rights for aboriginal people focuses on evidence from between the time of the people's first contact with Europeans to the time that the national sovereign power (in the case of the Sinixt, Great Britain) expressed 
sovereignty over that aboriginal territory. Thus, in the case of the Sinixt, the key dates are 1811, the date on which David Thompson first encountered the Sinixt, and 1846, the date of the Treaty of Oregon (between Great Britain and the United States).

The history of the earliest European maps of the region is very clear. The Sinixt occupied the aboriginal territory exclusively during that period [62]. A very good example of the type of cartographic evidence from the period is the map of Alexander Ross, dated 1821 (Figure 5).

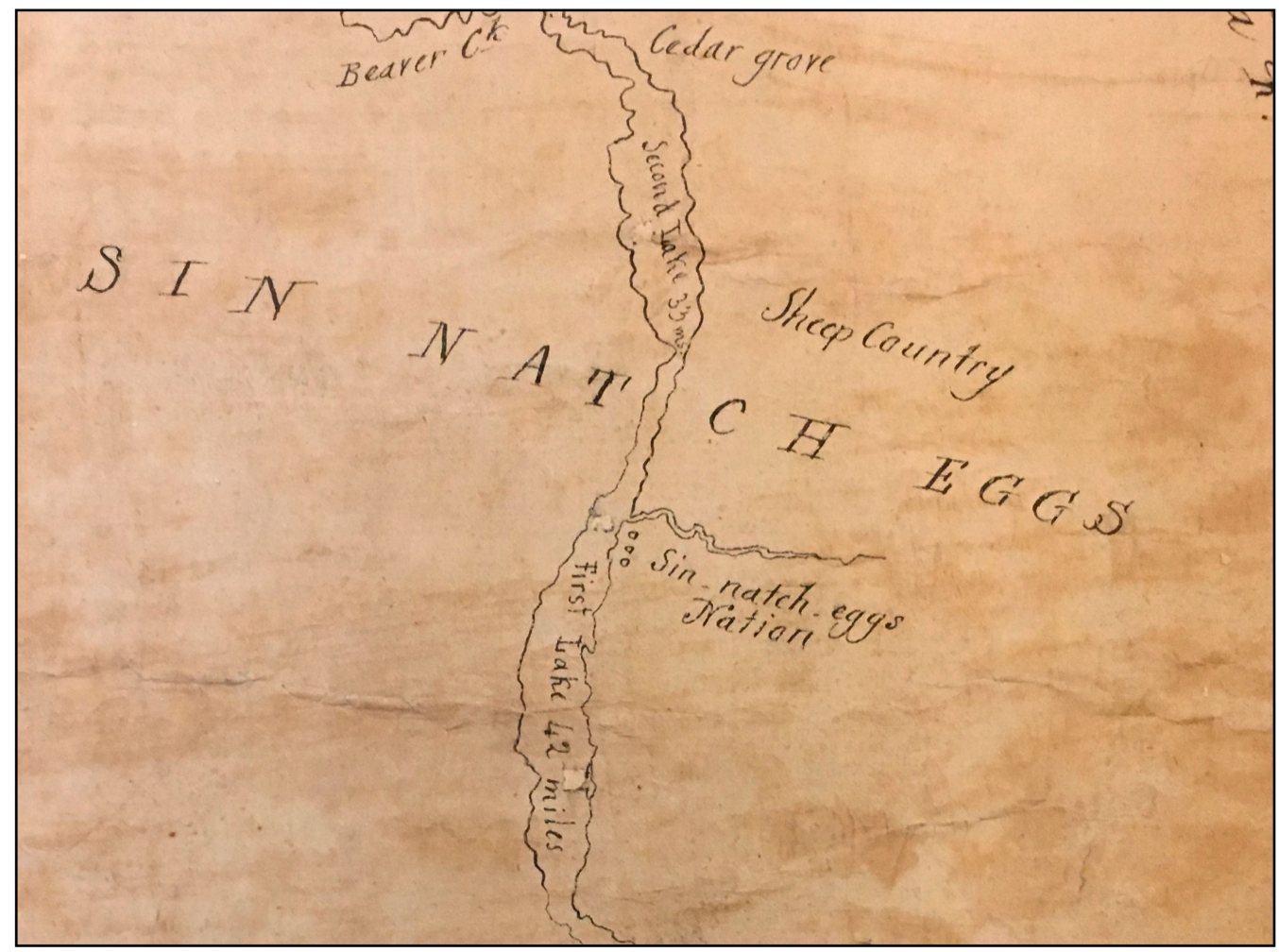

Figure 5. Detail from Ross, 1821. "Sin Natch Eggs" was Ross's spelling for "Sinixt." He placed the "Sin-natch-eggs Nation" on the Columbia River in the area of what are called today Upper and Lower Arrow Lakes.

The Sinixt are a perfect example of why the study of First Nation toponymy is so important. Colonial domination of First Nations included requiring tribal members to wear European-style clothing, to live in European-style homes and to eat European-style food. Native spirituality was to be replaced by organized Christian religion and punishment was dealt out to any child that even used one word of Native language. Traditional place-names were not accepted in aboriginal territory of the people and there was systematic renaming of those places in European languages. In the case of the Sinixt, what has been termed as "cultural genocide" included declaring the people extinct, wiping them completely off the map.

Now that the Canadian courts, to date, have acknowledged that the Sinixt are not extinct, it is especially important for the people to record and make prominently public their traditional environmental knowledge of the landscape (TEK) and the original names for places in their territory in their own language. The attached Sinixt place-name map represents the first stage of the Sinixt attempt to reclaim a portion of their ancient homeland and heritage (Figure 6). 


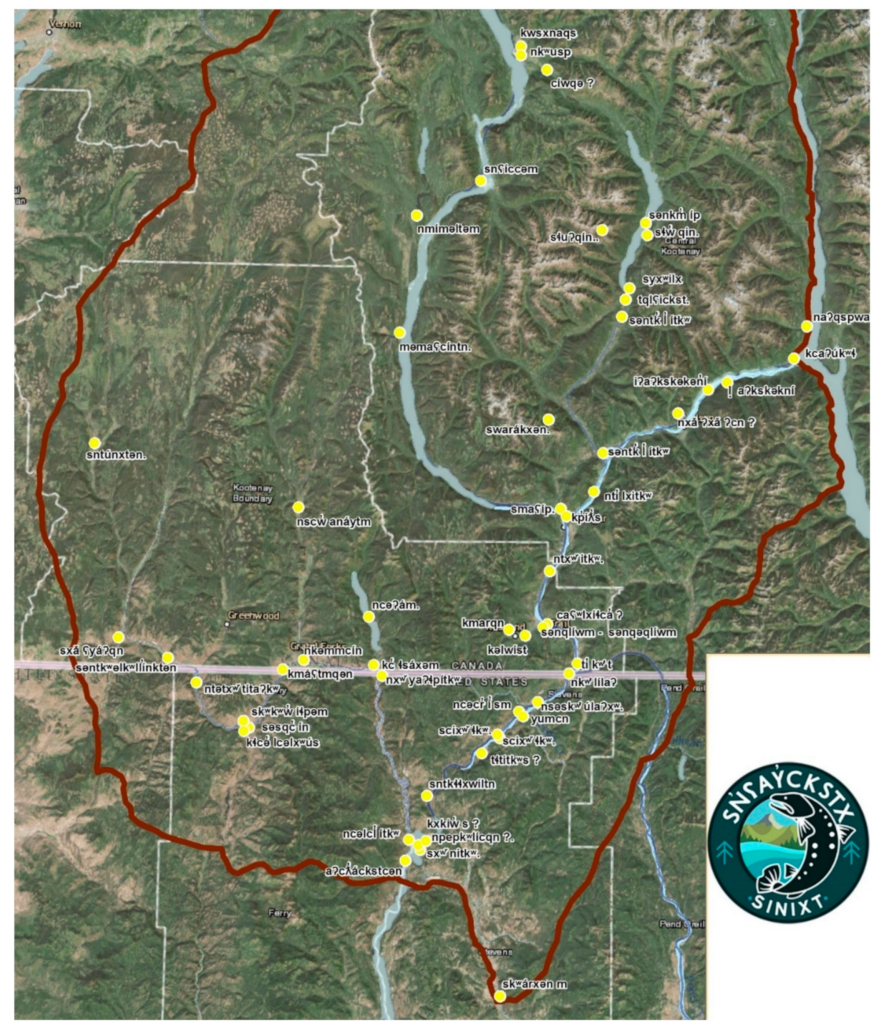

Figure 6. Detail from the sńiaýckstx (Sinixt) place-names map, currently under construction by the Tribe in collaboration with the Colville Confederated Tribes. This detail shows the Tribe's territory and selected place names from today's Nakusp north into British Columbia, and south to Kettle Falls in Washington State [63] (also See Supplementary Materials). Reprinted with permission from The Confederated Tribes of the Colville Reservation. Colville Confederated Tribes. 2021.

\section{Discussion}

Regardless of whether one looks at historical maps from nearly any place in North America or at present-day mapping and GIS activities, Native Americans and First Nations have shown considerable geographic intelligence of the cultural and physical landscapes that they and their neighbors occupy. Very often, their cognitive cartographic abilities enabled them to navigate these landscapes competently, and the descriptive place names that they assign to localities demonstrate a working knowledge that has served them well.

Today, the Sinixt are applying traditional pictographic knowledge and place-names to create a map that uses modern GIS technology to address toponymy in the region of their aboriginal territory. Although this project cannot undo the colonial damage to the tribal people, it is a first step in reconciling the Sinixt with their Aboriginal territory in British Columbia. The creation of this map will be an ongoing project for the Tribe, probably for many years to come. We envision that future research, like that with the Sinixt, will assist other Indigenous Nations in their efforts for recognition, land rights and accessibility to sacred sites, hunting and fishing.

Supplementary Materials: The full Sinixt territory and place-names poster (is available online from the GIS office of the Confederated Tribes: https:/ / drive.google.com/file/d/1cggWDHMb2 4clezpdEW7BARjMbIiF84/view?usp=sharing.

Author Contributions: Introduction, Daniel G. Cole; Colonial Period, Daniel G. Cole; 19th CenturyEarly 20th Century, Daniel G. Cole; Late 20thCentury-Early 21st Century, Daniel G. Cole; The Sinixt, E. Richard Hart; funding acquisition, E. Richard Hart. All authors have read and agreed to the published version of the manuscript. 
Funding: The portion of this research devoted to the Sinixt was funded by the Arrow Lakes Aboriginal Society and the Confederated Tribes of the Colville Reservation. No grant number was provided.

Institutional Review Board Statement: Not applicable.

Informed Consent Statement: Not applicable.

Data Availability Statement: Not Applicable.

Acknowledgments: We would like to acknowledge the GIS office of the Confederated Tribes of the Colville Reservation, which provided Figure 6 and the full map poster.

Conflicts of Interest: The authors declare no conflict of interest.

\section{References and Notes}

1. Lewis, G.M. Maps, Mapmaking, and Map Use by Native North Americans. In The History of Cartography; University of Chicago Press: Chicago, IL, USA, 1984; pp. 51-182. Available online: https://press.uchicago.edu/books/HOC/HOC_V2_B3/HOC_ VOLUME2_Book3_chapter4.pdf (accessed on 25 May 2021).

2. Library of Congress (LOC) Guide That Includes Much of Lewis' Work. Available online: https://guides.loc.gov/native-americanspaces/cartographic-resources/indian-maps-mapping (accessed on 25 May 2021).

3. Lewis, G.M. First Nations Mapmaking in the Great Lakes Region in Intercultural Contexts: A Historical Review. Mich. Hist. Rev. 2004, 30,1-34. Available online: https://www.jstor.org/stable/20174080?seq=1\#metadata_info_tab_contents (accessed on 25 May 2021). [CrossRef]

4. Lewis, G.M. Indian Maps: Their Place in The History of Plains Cartography. Great Plains Q. 1984, 4, 91-108. Available online: https:/ / www.jstor.org/stable/23531157?seq=1\#metadata_info_tab_contents (accessed on 25 May 2021).

5. De Champlain, S. Carte Geographique de la Nouvelle Franse; Leventhal Map Library: Boston, MA USA, 1613; Available online: https:/ / collections.leventhalmap.org/search/commonwealth:q524n3851 (accessed on 25 May 2021).

6. Smith, J. Virginia; LOC: Washington, DC, USA, 1624. Available online: https://www.loc.gov/item/99446115/ (accessed on 25 May 2021).

7. Hermann, M.J.; Pearce, M.W. They Would Not Take Me There; People, Places and Stories from Champlain's Travels in Canada; The University of Maine Canadian-American Center: Orono, ME, USA, 2008; pp. 1603-1616. Available online: https: / / umaine.edu/canam/publications / champlain-mapthey-would-not-take-me-there/ (accessed on 25 May 2021).

8. Catawba Deerskin Map. Map of the Several Nations of Indians to the Northwest of South Carolina; 1721. Available online: https:/ / www.loc.gov/item/2005625337/ (accessed on 25 May 2021).

9. Buache, P. Ochagach. Carte Physique des Terreins les Plus Eleves de la Partie Occidentale du Canada; David Rumsey Map Collection (DRMC); 1754. Available online: https://www.davidrumsey.com/luna/servlet/detail/RUMSEY \{\}8 \{\}1 \{\}306 194 \{\}90076573:Carte-physique-des-terreins-les-plu?sort=Pub_List_No_InitialSort\&qvq=w4s:/who\%2FBuache\%25252C\% 2BPhilippe\%25252C\%2B1700-1773;sort:Pub_List_No_InitialSort;lc:RUMSEY \{\}8 \{\}1\&mi=13\&trs=45 (accessed on 25 May 2021).

10. The Original Map by Ochagach is from The University of North Carolina Chapel Hill. Available online: http://rla.unc.edu/ Mapfiles/BSH3/BSH\%20B\%204044-84.HMC.3.jpg (accessed on 25 May 2021).

11. Cole, D.G. A Cartographic History and Analyses of Indian-White Relations in The Great Plains. In Digital Mapping and Indigenous America; Hess, J.B., Ed.; Routledge: New York, NY, USA, 2021.

12. Chegeree. Map of the Country about the Mississippi; LOC: Washington, DC, USA, 1755. Available online: https://www.loc.gov/item/74 695023 (accessed on 25 May 2021).

13. Montrésor, J. Copy of a Sketch of the Monongahela, with the Field of Battle; 1775. Available online: https://www.loc.gov/item/ gm71002314/ (accessed on 25 May 2021).

14. Red Head. Sketch of The River St. Lawrence from Lake Ontario to Montreal by an Onondaga Indian. 1759. With annotations and cartouches added by Guy Johnson. Available online: https://collections.leventhalmap.org/search/commonwealth:hx11z0861 (accessed on 25 May 2021).

15. De Brahm, J.G.W. Map of The Indian Nations in The Southern Department, Digital Library of Georgia. 1766. Available online: https:/ / dlg.usg.edu/record/guan_hmap_hmap1766d4\#item (accessed on 25 May 2021).

16. Helm, J. Matonabbee's Map. Arct. Anthropol. 1989, 26, 28-47. Available online: https://www.jstor.org/stable/i40013073 (accessed on 25 May 2021).

17. Comanche Pictograph Map of the Battle of Sierra Blanca; LOC: Washington, DC, USA, 1787. Available online: https://www.loc.gov / resource/g4322s.ct006428/ (accessed on 25 May 2021).

18. Viola, H.J. Smithsonian Expert Discusses Comanche Map; Friends of the Geography Map Division, Philip Lee Phillips Map Society of the Library of Congress, 2014; Volume 12, p. 3. Available online: https://www.loc.gov/rr/geogmap/pdf/plp/ plpnewsletters /2014/news2014fal.pdf (accessed on 3 June 2021).

19. Kohl, J.G. An Indian Map of The Upper-Missouri; 1801 with accompanying notes; LOC: Washington, DC, USA, 1850. Available online: https:/ / www.loc.gov/resource/g4127m.ct000579/ (accessed on 25 May 2021). 
20. Beattie, J.H. Indian Maps in the Hudson Bay Company Archives: A Comparison of Five Area Maps Recorded by Peter Fidler, 1801-1802. Archivaria 1985, 21, 166-175. Available online: https://archivaria.ca/index.php/archivaria/article/view/11246 (accessed on 3 June 2021). The second map covered a smaller area of north-central Montana and southern Alberta and Saskatchewan. The other maps were by an unknown Fall (Gros Ventre) Indian, Ki oo cus (Blackfoot), and by Ak ko wee ak (Blackfoot).

21. Steinke, C. "Here is my country": Too Né's Map of Lewis and Clark in the Great Plains. William Mary Q. 2014, 71, 589. [CrossRef]

22. Clark, W.; King, N.; Lewis, M. A Map of Part of the Continent of North America: Between the 35th and 51st Degrees of North Latitude and Extending from $89^{\circ}$ Degrees of West Longitude to the Pacific Ocean; With Accompanying Notes; LOC: Washington, DC, USA, 1804. Available online: https:/ /www.loc.gov/resource/g3300.ct000586/ (accessed on 25 May 2021).

23. Lewis, S.; Clark, W.; Harrison, S. A Map of Lewis and Clark's Track, across the Western Portion of North America from the Mississippi to the Pacific Ocean: By Order of the Executive of the United States in 1804, 5 \& 6; LOC: Washington, DC, USA, 1814. Available online: https:/ / www.loc.gov / resource/g4126s.ct000028/ (accessed on 25 May 2021).

24. Gribb, W.J.; Cole, D.G. The Use of GIS to Analyze the Native American Tribal Information from the Lewis and Clark Corps of Discovery. Chapter 8. In Mapping Native America: Cartographic Interactions between Indigenous Peoples, Government, and Academia; Volume I, Cartography and the Government; Cole, D.G., Imre, S., Eds.; CreateSpace Pub.: Charleston, SC, USA, 2014 ; pp. 175-176.

25. Mooney, J. The Aboriginal Population of America North of Mexico. In Smithsonian Miscellaneous Collections; Smithsonian Institution: Washington, DC, USA, 1928; p. 80, No. 1, Publication 2955.

26. Boyd, R.T. Demographic History until 1990. In Handbook of North American Indians; Walker, D.E., Ed.; Smithsonian Institution: Washington, DC, USA, 1998; Volume 12, pp. 467-483.

27. Parry, W.E. Eskimaux Chart No. 3, The Shaded Parts Drawn by Ewerat at Winter Island; Carter Brown Map Collection; 1822. Available online: https://jcb.lunaimaging.com/luna/servlet/workspace/handleMediaPlayer?qvq=w4s $\% 253 \mathrm{~A} \% 252 \mathrm{Fwhat} \%$ 252FArctic\%2bregions--Maps\&trs=12\&mi=1\&lunaMediaId=JCB \{\}1 \{\}1 \{\}4058 \{\}6400004 (accessed on 25 March 2021).

28. Lyon, G.F. Eskimaux Chart No. 1, Drawn by Iligliuk at Winter Island; 1822. Available online: https://jcb.lunaimaging.com/ luna/servlet/workspace/handleMediaPlayer?qvq=w4s\%253A\%252Fwhat\%252FArctic\%2bregions--Maps\&trs=12\&mi=4\& lunaMediaId=JCB \{\} $1 \sim\{\} 1 \sim\{\} 4129 \sim\{\} 6410001$ (accessed on 25 May 2021).

29. Gero-Schunu-Wy-Ha's Map Is in the Cartographic and Architectural Branch, Record Group 75, Map 931, National Archives, College Park, MD. Non-Chi-Ning-Ga's map is in the Cartographic and Architectural Branch, Record Group 75, Map 821, National Archives, College Park, MD.

30. Nicollet, J.N.; Fremont, J.C.; Stone, W.J. Hydrographical Basin of the Upper Mississippi River from Astronomical and Barometrical Observations, Surveys, and Information; LOC: Washington, DC, USA, 1843. Available online: https://www.loc.gov/resource/g404 2m.ct001419/ (accessed on 25 May 2021).

31. Bernstein, D. How the West Was Drawn: Mapping, Indians, and the Construction of the Trans-Mississippi West; University of Nebraska Press: Lincoln, NE, USA, 2018; pp. 172-193.

32. Gregg, J.; Morse, S.E.; Breese, S. A Map of the Indian Territory: Northern Texas and New Mexico, Showing the Great Western Prairies; David Rumsey Map Collection; Stanford University: Stanford, CA, USA, 1844; Available online: https://www.davidrumsey.com/ luna/servlet/detail/RUMSEY \{\}8 \{\}1 \{\}261609 \{\}5523519:A-map-of-the-Indian-territory---Nor?sort=Pub_List_No_InitialSort\& qvq=w4s:/who\%2FGregg\%25252C\%2BJosiah;sort:Pub_List_No_InitialSort;lc:RUMSEY \{1\}8 \{\}1\&mi=0\&trs=10 (accessed on 25 May 2021). This is another example of an American relying on an Indigenous informant was in 1844, when Joshua Gregg published a book that included a map he drafted of Indian nation lands, reservations, hunting grounds, villages, pueblos, along with trade routes, migratory trails, military expeditions, forts and trading posts, missions, hydrology and topography. As Bernstein notes (pp. 9-10), Gregg heavily relied on Comanche Chief Tabba-quenna (Big Eagle), who drew him a map (that likely was not saved) which accurately portrayed all of the major rivers from Missouri to Santa Fe along with a number of Mexican settlements.

33. The Pierre-Jean de Smet Map Collection, The Jesuit Archives and Research Center. Available online: https://jesuitarchives. omeka.net/items/browse? collection=5\&page=1 (accessed on 25 May 2021).

34. De Smet, P.-J. Map of the Upper Great Plains and Rocky Mountains region; LOC: Washington, DC, USA, 1851. Available online: https:/ / www.loc.gov/item/2005630226/ (accessed on 25 May 2021).

35. Denig, E.T. Anonymous Assiniboine Map of the North Side of Missouri River from Fort Union to Fort Benton; National Anthropological Archives (NAA). 1853. Available online: http://collections.si.edu/search/detail/ead_component: sova-naa-ms2600b1-ref19?q=map+of+the+north+side+of+teh+missouri+river\&record=2\&hlterm=map $\% 2 \mathrm{Bof} \% 2 \mathrm{Bthe} \%$ 2Bnorth\%2Bside\%2Bof\%2Bteh\%2Bmissouri\%2Briver\&inline=true (accessed on 25 May 2021).

36. Warhus, M. Another America: Native American Maps and the History of Our Land; St. Martin's Press: New York, USA, 1997.

37. Boas, F. Maps of Parts of Baffin Island Drawn by Eskimos. 1883. Available online: https://sova.si.edu/details/NAA.MS169270 (accessed on 25 May 2021).

38. Crazy Mule's Maps Are Extensively Discussed in Fredlund, Glen, Linea Sundstrom, and Rebecca Armstrong. Crazy Mule's Maps of the Upper Missouri, 1877-1880. Plains Anthropol. 1996, 41, 5-27, Crazy Mule's Maps Covered Areas Including: The Upper Missouri, Yellowstone and Milk River Watersheds, and Western Dakota.

39. Black Goose. Map of Kiowa Reserve; NAA. 1904. Available online: http:/ / collections.si.edu/search/results.htm?q=\%23E233091 (accessed on 25 May 2021). 
40. Meadows, W.C. 'We want our land as it is': Black Goose's Map as an Example of Kiowa Political Cartography. In Mapping Native America: Cartographic Interactions between Indigenous Peoples, Government, and Academia; Volume III, Cartography and Indigenous Autonomy; Cole, D.G., Sutton, I., Eds.; CreateSpace: Charleston, SC, USA, 2014; pp. 35-67.

41. Blish, H.H. A Pictographic History of the Oglala Sioux, 50th Anniversary Ed.; University of Nebraska Press: Lincoln, PA, USA, 2017; Maps of the Battle of the Little Big Horn Are Seen on pp. 215 and 256; Battle of the Rosebud on p. 188; Fights with the Crow on pp. 185-186, and 396; of the Black Hills Region on pp. 287-288; and a Fight with the Cheyenne on p. 391.

42. Bolich, D.W. State of Sequoyah; LOC: Washington, DC, USA, 1905. Available online: https://www.loc.gov/resource/g4021g.ct011168/ (accessed on 25 May 2021).

43. Tribal GIS: Supporting Native American Policies with GIS; Sappington, N.; Gadsden, D.; Taylor, A.; Thomas, C. (Eds.) Esri Press: Redlands, CA, USA, 2008.

44. Tribal GIS: Supporting Native American Decision Making; Taylor, A.; Gadsden, D.; Kerski, J.; Warren, H. (Eds.) Esri Press: Redlands, CA, USA, 2012.

45. Tribal GIS: Supporting Native American Policies with GIS; Taylor, A.; Guglielmo, H.; Thomas, C. (Eds.) Esri Press: Redlands, CA, USA, 2013.

46. Tribal GIS: Supporting Native American Decision Making; Taylor, A.; Gadsden, D.; Kerski, J.; Guglielmo, H. (Eds.) Esri Press: Redlands, CA, USA, 2017.

47. The BIA's Branch of Geospatial Support. Available online: https:/ / www.bia.gov/gis (accessed on 25 May 2021).

48. Village Earth's Website. Available online: http:/ / www.lakotalands.net/ (accessed on 25 May 2021).

49. Map of Pine Ridge IR. Available online: https://villageearth.maps.arcgis.com/apps/MapTools/index.html?appid=bdfebb55407 447f1b6d3705c3fe7e0bf (accessed on 25 May 2021).

50. The Story Map. Available online: https:/ / www.ntkp.ca/ (accessed on 25 May 2021).

51. The Bilingual Government Map. Available online: https://www.aadnc-aandc.gc.ca/Map/irs/mp/index-en.html (accessed on 25 May 2021).

52. The Gwich'in Place Names Atlas. Available online: https://atlas.gwichin.ca/index.html (accessed on 25 May 2021).

53. The Firelight Group Is headed by Steve DeRoy. Available online: https:/ / firelight.ca/mapping-and-gis/ (accessed on 25 May 2021).

54. The Indigenous Mapping Workshops. Available online: https://www.indigenousmaps.com/ (accessed on 25 May 2021).

55. The Description of Pearce's Poster Map, with Access to Download a PDF Copy. Available online: https://umaine.edu/canam/ publications / coming-home-map/ (accessed on 25 May 2021).

56. Chapman, J.D.; Turner, D.B. British Columbia Atlas of Resources. In Proceedings of the British Columbia Natural Resources Conference, Vancouver, BC, Canada, 22-24 February 1956. The atlas was accompanied by another volume of text. Also see: Chapmen, et al. Transactions of the Ninth British Columbia Natural Resources Conference. In Proceedings of the British Columbia Natural Resources Conference, Victoria, BC, Canada, 22-24 February 1956.

57. Chapman, J.D.; Turner, D.B. Atlas of Resources. In Proceedings of the British Columbia Natural Resources Conference, Vancouver, BC, Canada, 22-24 February 1956. The atlas was published in preparation for the 1958 centenary of British Columbia. The atlas celebrates the provinces' "endowment, as it was one hundred years ago and as it is today."

58. Chapman, J.D.; Turner, D.B. British Columbia Atlas of Resources. In Proceedings of the British Columbia Natural Resources Conference, Vancouver, BC, Canada, 22-24 February 1956; Map 30. pp. 61-62.

59. Transactions of the Ninth British Columbia Natural Resources Conference. In Proceedings of the British Columbia Natural Resources Conference, Victoria, BC, Canada, 22-24 February 1956; p. 519.

60. Indian Affairs Branch. "Indians of Arrow Lake," Digest Extract from Annual Reports, Mrozinski, Judge L. “Reasons for the Judgment of the Honourable Judge L. Mrozinski," Regina v. Richard Lee Desautel, 2017. BCPC 84, File No. 23646, Registry Nelson, Date 27 March 2017, pp. 7, 15.

61. Mrozinski, J.L. Reasons for the Judgment of the Honourable Judge L. Mrozinski. Regina v. Richard Lee Desautel 2017. BCPC 84, File No. 23646, Registry Nelson, Date 27 March 2017.

62. Hart, E.R. Maps Showing Sinixt Territory, 1811-1845. Cartogr. The Int. J. Geogr. Inf. Geovis. 2020, 55, $219-240$.

63. The Full Sinixt Territory and Place Names Poster Is Available from the GIS Office of the Confederated Tribes. At the Request of the Tribe, Dr. Anthony Matinna Standardized the Place Names Orthography. Available online: https://drive.google.com/file/d/ 1cggWDHMb2x_4cIezpdEW7BARjMbIiF84/view?usp=sharing (accessed on 25 May 2021). 